\title{
Socio-economic Status of Rickshaw Pullers in Lucknow City, Uttar Pradesh (India)
}

Milind Sen ( $\nabla$ senmilindsen@gmail.com )

senmilindsen@gmail.com https://orcid.org/0000-0002-8804-9014

\section{Article}

Keywords: Rickshaw pullers, Socio-economic status, health, migration, and marginalized

Posted Date: February 9th, 2022

DOI: https://doi.org/10.21203/rs.3.rs-1323649/v1

License: (9) This work is licensed under a Creative Commons Attribution 4.0 International License. Read Full License 


\section{Abstract}

This paper is based on the empirical study done in 2019 on 75 rickshaw pullers. The data was collected randomly from different places in Lucknow city such as Railway stations, Bus stands, CBD, and residential areas. However, the study is based on interview scheduled, semi-structured questions, an openended question such as religions, castes, age, marital status, literacy level, previous occupation, living conditions, family members dependents, local or migrated, and health issues of the respondents. The rickshaw pullers are low-income group people and marginalized. The study has found the socioeconomic conditions of the Rickshaw pullers poor. The study has highlighted the RP's socio-economic status, health, wellbeing, and living conditions are not good both origin place and destination.

\section{Introduction}

The postmodern Indian the cities rapidly growing urbanization, 2001 census 27.8 to $31.16 \%$ (The Census of India, 2011). However, The Indian city's growth is due to urbanization which provides a better opportunity for livelihood to migrants. The rural-urban migration is due to an overburden on agriculture, lack of local job opportunities, and big family size and pushing urban cities for a sustainable life. Rickshaw pullers have low earned and hazardous occupations, accompanied by low social status and illness(Warren, 1985) . Unsustainable and vulnerable in terms of assets, income, environment, health, and other social services (Begum \& Sen, 2012). Uttar Pradesh is one of the BIMARU states due to development activities and better urban amenities such as transport networking, better health care, a better educational institute in the periphery, and better job opportunities attract rural people towards cities (Ali, 2013). Rickshaw pullers earn low earning professions and hazardous occupations, accompanied by low social status and illness. The southeast Asian countries and South Asia. During the colonial period apt as this occupation who's emigrated agricultural laborers within cities, The social organization of a coolie occupation role that rickshaws and rickshaw pullers played in Singapore's history, and the marginalized lives the coolie led (Warren, 1985). Rickshaw pullers come from poor socio-economic backgrounds consistent with the characteristics of chronic poverty. This occupation provides a route of modest upward mobility for those among the rural chronic poor who come to the city for work. Rickshaw pullers are prone to health risks. This profession represents an unsustainable livelihood, as the initial welfare gain points off with a length of contribution in this profession. Thus, intergenerational mobility in this occupation is limited choices another occupation for their children (Begum \& Sen, 2012). The study tends to explore socio-economic and demographic data collected in an assemblage of a structured schedule and, semi-structured interview collected information related to the personal details like name, age, local or migrated, educational level, previous occupation, daily working hours, daily earning, seasonal or permanent, owner of a rickshaw or rented, religion, castes, marital status, dependent no. of family members, Family profession, Reason of entered Rickshaw pulling, are you aware welfare government schemes, health status, are you any serious diseases, bad habits e.g., Alcohol, cigarette bidi, tobacco etc.

\section{Area of the Study}


The geographical extension of Lucknow is $26 \rrbracket 30^{\prime} \mathrm{N}$ to $27 \otimes 10^{\prime} \mathrm{N}$ latitudes and $80 \otimes 30^{\prime} \mathrm{E}$ to $81 \otimes 13^{\prime} \mathrm{E}$ longitudes. Lucknow is the capital city of Uttar Pradesh. Lucknow is situating in river Gomati, a left-bank tributary of river Ganga. It spread the north by Sitapur, on the southeast by the Rae Bareli, on the northeast by Barabanki, on the northwest by Hardoi, and the southwest by Unnao district(Kumari, 2015). As fig.01. Lucknow attracts migrants in search of better employment opportunities and higher-order services like education and health(JNNURM and Chennai Metropolitan Development Authority, 2006).

\section{The objective}

- To examine socio-economic status and demographic profile of the respondents

- To analysis the reason behind adopted rickshaw pulling as livelihood.

- To explored influence of caste and social background of the respondents on their occupation.

\section{Methodology}

The study has conducted in 2019,75 respondents from Lucknow city, Uttar Pradesh, India. The method has used random sampling in different areas of the city. The question asked the socio-economic profile of the respondents. Interviewed scheduled has been used for captured data related to religion, caste, age, marital status, local or migrated, literacy level, earnings per day, daily working hours, health condition, and living condition of the respondents. The data analysis has sample descriptive statistics as a diagram, pie charts, table, percentage, and bar graph.

\section{Data Analysis And Discussion}

\section{Socio-economic condition and demographic profile of the Rickshaw Pullers:}

Rickshaw pullers are lower strata of the society and historically excluded. They are rural to urban migration due to agricultural distress and lack of the local job opportunities to push rural mobility toward urban searching better livelihood. However, Rickshaw pulling is arduous work in informal sectors. They are illiterate, poor, unskilled, semi-skilled. They have adopted the rickshaw pulling easy entry, instant income, and no need for formal education or any skill. They are adopting rickshaws pulling as a profession for the feed belly of their family members. They are most landless laborers, agricultural workers, daily wages workers, Constructed works, and other menial works. Thus, they are rural migrant's different districts of Uttar Pradesh and the rest of the country. They have married early age, the family responsibilities big reason for entering this profession.

Bar graph no.01 Shows no of the rickshaw pullers entry early age adopted rickshaw pulling. The study has found mostly age-groups 25-40 years, while Minimum numbers of them lie under the $>50$ years. Rickshaw pullers are hard, competition within the occupation and modern short-distance city means of transportation. The rickshaw pulling profession uncertain jobs opportunity in this occupation. 
Bar-graph no. 02 Shows that the daily average earning of the rickshaw pullers was 65 respondents earning between Rs.100-250 while ten respondents were earning more than Rs.250-300 rupee. Rickshaw pullers are low-earning groups. They are facing intergenerational abject poverty.

Piechart no.01 Shows $60 \%$ of the rickshaw pullers paid Rs. 40 per day to hire the old rickshaw while $40 \%$ of rickshaw pullers hired new rickshaw paid Rs.50 per day from the rickshaw owners. The study has found that rickshaw pullers sometimes didn't earn enough money to pay rickshaw rent and two-time foods. The study did not find the owner of the rickshaw pullers.

Bar-graph no.03 shows that in family sizes 58 respondents 3-11 family members, while only 17 respondents have 0-2 family members. They are come from poor socio-economic backgrounds to hard tasks to one person, solely on the earning of the rickshaw pulling Rs.100-200 per day bearing big size of the family. They are illiterate, have chronic poverty, and have no alternative jobs opportunities to enhance income.

Pie-chart no.02 shows 77 percent of rickshaw pullers are migrating rickshaw pulling to the city while only 23 percent are local residents. Mostly rickshaw pullers are seasonal migrants to earn a sustainable livelihood, from rural areas (different neighboured districts in Uttar Pradesh, rest of the country), and among most of them the agricultural laborers or landless workers and menial workers.

Table No.1 Previous Occupation of Rickshaw Pullers

\begin{tabular}{|l|l|l|l|}
\hline Sl. no & Occupation & Respondents & Percentage \\
\hline $\mathbf{1}$ & Farmers & 2 & 2.5 \\
\hline $\mathbf{2}$ & Bricks Kiln & 7 & 9.4 \\
\hline $\mathbf{3}$ & Construction labour & 11 & 14.7 \\
\hline $\mathbf{4}$ & Landless worker & 25 & 33.4 \\
\hline $\mathbf{5}$ & Agricultural labour & 30 & 40 \\
\hline & Total & $\mathbf{7 5}$ & $\mathbf{1 0 0}$ \\
\hline
\end{tabular}

\section{Source: Based on field survey January, 2019.}

Table no.01 shows 97.5 percent rickshaw pullers are the previous occupation of the agricultural laborers, bricks kiln, landless workers, construction workers, while only 2.5 percent farmers.

Bar-graph no.04 Shows 60 numbers of the respondents Hindus and within Hindu's caste,37 number of the rickshaw pullers scheduled castes, 18 numbers of OBCs and six number of general categories and poverty no exception in general categories, while 14 numbers of Muslins.

Pie-chart no.03 shows that 93.33 percent of the rickshaw pullers married respondents and only 6.67 percent unmarried. The study found rickshaw pullers have got early age married felt the family 
responsibilities compelled dependents to feed the belly. they are suffering intergenerational abject poverty and enter this occupation while unmarried respondents enter this profession due to poor conditions.

Bar-graph no.05 Shows 29 numbers of the respondents are an educational level of the rickshaw pullers illiterate and only two numbers of the respondents intermediate and rest respondents of the primary, secondary or high school failed. They were excluded from higher education due to poor socio-economic conditions and early age adopt rickshaw pulling.

Bar-graph no.06 Shows 66 numbers of the rickshaw pullers living on a footpath, Jhuggies /slums and own rickshaw passed night while only six respondents rented house. The study has found mostly respondents living single room 3 to 5 members, share kitchen, toilets, use public place, and unhygienic living condition.

Bar-graph no. 07 Shows that 59 respondents daily working hours between 7-12, while only 17 respondents per day 4-6. The study has found most of the respondents start early morning to midnights to rickshaw pulling. Rickshaw pulling is arduous work. They are working more than 12 hours but they are hardly getting 4 to 5 hours. The study has found most young rickshaw pulling earnings are more than elderly rickshaw pullers.

Bar-graph no.08 shows that 42 numbers rickshaw pullers have tobacco, 55 numbers bidi, 16 numbers alcohol, 61 numbers pan Mashal addicted. They are hard earning spend on the addicted, due to hard work from exit pain.

Bar-graph no.09 shows that 35 Rickshaw pullers have a cough 29 numbers have joint pain, eight respondents have asthma and three respondents have chest pain. Rickshaw pulling is hard physical work. They have a lot of bad habits such as smoking, chewing, and drinking due to many types occurred health issues. However, they are most self-Medicare, medical stores. They are most of the income spent on health and other essential thing. These have increased deterioration conditions.

\section{Finding And Conclusion}

Uttar Pradesh is the most backward state among the BIMARU States(Ali, 2013). The study has found more the 90 percent of rickshaw pullers landless and menial workers. The study has highlighted the socio-economic condition of rickshaw pullers origin, and destination place is not good. However, they are moving to cities due to the distressed primary sectors and no local jobs. The study has found 93.33 percent of respondents got early marriage due to family pressure. The study has found that 77 percent of respondents migrated from different districts of Uttar Pradesh and most disadvantaged sections of the society. The study has revealed rickshaw pullers suffer from intergenerational poverty. However, the double competition within an occupation and modern short distance city transports e.g., E-rickshaw, Autorickshaw. Rickshaw pulling is needed physical fit person. They have to make availability from early morning to late night, but hardly Rs.100-200 daily earnings. However, the study found most of the hard earnings spent on rickshaw rent, medicine, another essential thing, sometimes not even enough to pay 
rickshaw rent or two-time foods. The study has found negligible availability of social security scheme of rickshaw pullers. They are addicted of bad habits such as bidi, alcohol, tobacco, pan Mashal. Most of the rickshaw pullers were affected by diseases. The study has highlighted 60 respondents Hindus, and the rest of Muslims, within Hindus,37 rickshaw pullers belonged scheduled castes, 18 other backward classes. The study has highlighted rickshaw pullers don't have basic facilities at the workplace such as proper housing, unhygienic living conditions, ration cards, health care, and bank account. The study has found negligible pension holders among rickshaw pullers. More than 90 percent RPs have migrated alone and spend nights on a rickshaw, railway, and Bus stand. The government should carry forward and design an appropriate policy framework in collaboration with private entrepreneurs to create a sustainable livelihood. Private players and NGOs can strengthen the skill development programs and replace the menial peddling and hand-pulled with e-rickshaw.

\section{Declarations}

\section{Acknowledgement}

I thank the Indian Council of Social Science Research (ICSSR), New Delhi, for the awarded Doctoral fellowship (2017-18) for financial support for my Ph.D. work. I would also like gratefully to you for my Ph.D. Supervisor, Prof.K. Raja Mohan Rao, at Centre for the Study of Social Exclusion and Inclusive Policy, University of Hyderabad, Telangana, India, and also indebted to CSSEIP Staffs and Faculty for their support and guidance.

\section{References}

Ali, M. (2013). Socio-Economic Analysis of Rickshaw Pullers in Urban Centres: A Case Study of Uttar Pradesh, India ISSN: 2278-6236 SOCIO-ECONOMIC ANALYSIS OF RICKSHAW PULLERS IN URBAN CENTRES: A CASE STUDY OF UTTAR PRADESH, INDIA. IJARMSS, Vol.2(January), No.1.

Begum, S., \& Sen, B. (2012). Unsustainable Livelihoods, Health Shocks and Urban Chronic Poverty: Rickshaw Pullers as a Case Study. SSRN Electronic Journal, November. https://doi.org/10.2139/ssrn.1754402

JNNURM and Chennai Metropolitan Development Authority. (2006). City Development Plan. July, 195. http://jnnurm.nic.in/wp-content/uploads/2010/12/CDP_Delhi.pdf

Kumari, K. (2015). Urban Sprawl: A Case Study of Lucknow City. International Journal of Humanities and Social Science Invention, 4(5), 11-20. http://www.ijhssi.org/papers/v4(5)/Version-2/B0452011020.pdf

The Census of India. (2011). The Census of india 2011 report pdf. Goi. https://www.google.co.in/search? client=safari\&rls=en\&q=census+of + India $+2011+$ report\&ie=UTF-8\&oe=UTF8\&gfe_rd=cr\&ei=dia4VqrsJceL8QeXuom4Aw\#q=census+of+india+2011+report+pdf 
Warren, J. (1985). The Singapore Rickshaw Pullers: The Social Organization of a Coolie Occupation, 1880-Author ( $s$ ): Jim Warren Published by: Cambridge University Press on behalf of Department of History , National University of Singapore Stable URL : https://www.jstor. 16(1), 1-15.

\section{Graphs And Charts}

Bar-graphs 1-9 and Pie-charts 1-3 are available in the Supplemental Files section

\section{Figures}

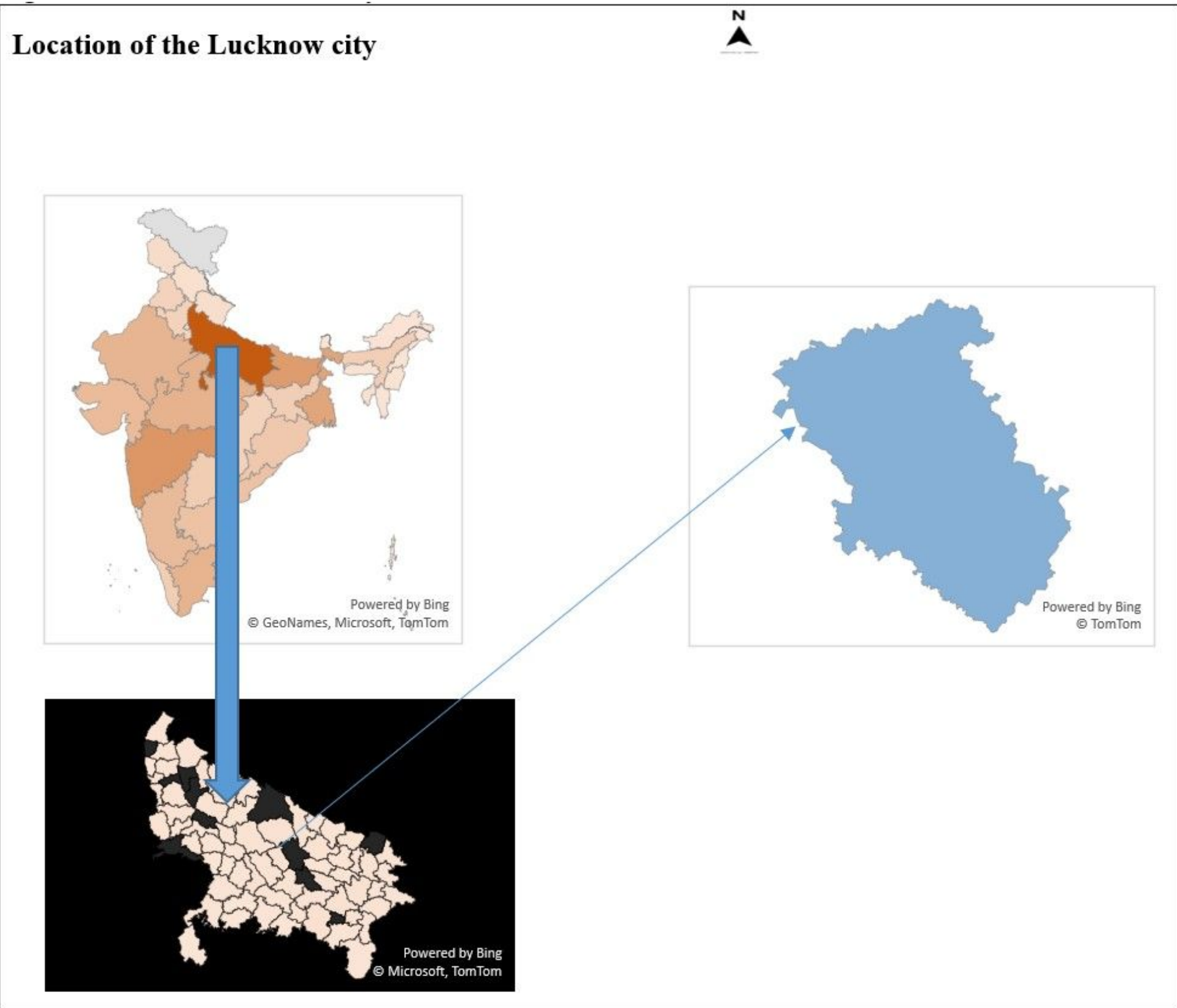

Figure 1

Location of the study area Lucknow, 


\section{Supplementary Files}

This is a list of supplementary files associated with this preprint. Click to download.

- drawingimage3.png

- drawingimage4.png

- drawingimage5.png

- drawingimage6.png

- drawingimage7.png

- drawingimage8.png

- drawingimage9.png

- drawingimage10.png

- drawingimage11.png

- drawingimage12.png

- drawingimage13.png

- drawingimage14.png 